\title{
APLIKASI GRADASI GABUNGAN DI LABORATORIUM DAN GRADASI HOT BIN ASPHALT MIXING PLANT CAMPURAN LATASTON (HRS - BASE) TERHADAP KARAKTERISTIK MARSHALL
}

\author{
Welem Daga ${ }^{1}$, Theodorus Paling ${ }^{2}$, Yermias E. Lay ${ }^{3}$
}

\begin{abstract}
Abstrak :
Perencanaan yang baik terkadang meleset dalam pelaksanaannya, yang akibatnya akan berdampak pada masyarakat pengguna jalan. Komposisi gradasi perkerasan lentur yang digunakan sering tidak sesuai dengan desain perencanaan dan peruntukkannya.

Banyak upaya yang dilakukan untuk melihat kembali komposisi yang digunakan gradasi yang digunakan. Diantaranya dengan melihat perbandingan gradasi gabungan di laboratorium dengan gradasi gabungan pada unit Hot Feed Bin di Asphalt Mixing Plant (AMP) yang berbeda jauh, juga sering menghadapi kendala akibat tidak pernah diadakan kalibrasi pada saringan yang ada pada unit Hot Feed Bin di AMP.

Dari faktor sumber daya manusia sering diakibatkan oleh sikap para operator pelaksana perkerjaan konstruksi jalan yang amat sering mengabaikan pentingnya pengukuran dan kalibrasi gradasi gabungan di laboratorium, maupun gradasi gabungan di unit Hot Feed Bin di Asphalt Mixing Plant (AMP). Sering terjadinya pencampur-bauran agregat dalam muatan bin, tipe yang benar dari feeders, termasuk tipe belt untuk agregat pasir halus, pintu feeders jarang dikalibrasi secara tepat dan terpasang dengan kuat, tidak terjaganya secara terpisah ukuran agregat di lokasi stockpile, menjadi penyebab penyimpangan pada Job Mix Agregate Formula (JMAGF).

Penelitian komparasi aplikasi gradasi gabungan di laboratorium dan gradasi di unit Hot Feed Bin Asphalt Mixing Plant (AMP) yang mengacu pada Spesifikasi Baru Beton Aspal Campuran Panas perlu dilakukan untuk mendapatkan kinerja gradasi Job Mix Agregate Formula (JMAGF) campuran Lataston (HRS - Base) di Laboratorium dan membandingkannya dengan gradasi Job Mix Agregate Formula (JMAGF) dengan kadar aspal yang sama campuran Lataston (HRS -Base) di unit Hot Feed Bin Asphalt Mixing Plant (AMP).
\end{abstract}

Kata kunci: AMP, JMF, Karakteristik Marshall.

\section{PENDAHULUAN}

Pembinaan jalan yang hasilnya dapat memenuhi tuntutan masyarakat pengguna jalan bukanlah pekerjaan yang mudah, terlebih pada saat kondisi anggaran terbatas serta beban kendaraan yang cenderung jauh melampaui batas dan kondisi cuaca yang kurang bersahabat.
Disamping itu, makin meningkatnya kesadaran masyarakat untuk menyampaikan tuntutannya atas penyediaan prasarana jalan merupakan tantangan yang perlu mendapat perhatian dari pihak-pihak yang terkait dalam pembinaan jalan. Aspek tersebut merupakan kenyataan yang tidak bisa dihindari dan perlu dijadikan pendorong 
untuk mencari upaya yang dapat meningkatkan pembinaan jalan secara efektif dan efisien, baik pada pembangunan jalan baru maupun pada pelaksanaan pemeliharaan / peningkatan jalan yang ada.

Perencanaan yang baik terkadang meleset dalam pelaksanaannya, yang akibatnya akan berdampak pada masyarakat pengguna jalan. Komposisi gradasi perkerasan lentur yang digunakan sering tidak sesuai dengan desain perencanaan dan peruntukkannya. Banyak upaya yang dilakukan untuk melihat kembali komposisi yang digunakan gradasi yang digunakan. Diantaranya dengan melihat perbandingan gradasi gabungan di laboratorium dengan gradasi gabungan pada unit Hot Feed Bin di Asphalt Mixing Plant (AMP) yang berbeda jauh, juga sering menghadapi kendala akibat tidak pernah diadakan kalibrasi pada saringan yang ada pada unit Hot Feed Bin di $A M P$. Dari faktor sumber daya manusia sering diakibatkan oleh sikap para operator pelaksana perkerjaan konstruksi jalan yang amat sering mengabaikan pentingnya pengukuran dan kalibrasi gradasi gabungan di laboratorium, maupun gradasi gabungan di unit Hot Feed Bin di Asphalt Mixing Plant (AMP).

Sering terjadinya pencampur-bauran agregat dalam muatan bin, tipe yang benar dari feeders, termasuk tipe belt untuk agregat pasir halus, pintu feeders jarang dikalibrasi secara tepat dan terpasang dengan kuat, tidak terjaganya secara terpisah ukuran agregat di lokasi stockpile, menjadi penyebab penyimpangan pada Job Mix Agregate Formula (JMAGF).

Serta contoh asal agregat berasal dari Lokasi stockpile yang berada pada kali Ex Pariti Bipolo - Kabupaten Kupang, lokasi stockpile yang sering digunakan membuat minimnya pengawasan pada proses pencampur-bauran agregat.

Berdasarkan permasalahan tersebut perlu dilakukan penelitian komparasi aplikasi gradasi gabungan di laboratorium dan gradasi di unit Hot Feed Bin Asphalt Mixing Plant (AMP) Bipolo pada campuran Lataston (HRS - Base) terhadap karakteristik uji Marshall, yang mengacu pada Spesifikasi Baru Beton Aspal Campuran Panas.

\section{KAJIAN PUSTAKA}

\subsection{Campuran Beraspal Panas}

Dalam spesifikasi terdapat beberapa jenis campuran beraspal, yaitu :

a.Latasir (Lapis Tipis Aspal Pasir)

b.Lataston (Lapis Tipis Aspal Beton)

c. Laston (Lapis Aspal Beton)

\section{a.Lapis Tipis Aspal Pasir (Latasir, HRSS) kelas A dan B}

Campuran ini dimaksudkan untuk jalan dengan lalu-lintas ringan $(<0,5$ juta ESA/ tahun), terutama di daerah dimana batu pecah sulit diperoleh, biasa digunakan untuk lapis permukaan.

Pemilihan Latasir kelas A atau B tergantung pada gradasi pasir yang digunakan. Campuran Latasir biasanya memerlukan tambahan bahan pengisi untuk memenuhi sifat-sifat campuran yang disyaratkan. Campuran jenis ini umumnya mempunyai daya tahan yang relatif rendah terhadap terjadinya alur, karena itu tidak dibenarkan dipasang dengan lapisan yang tebal, pada jalan dengan lalu-lintas berat atau pada daerah tanjakan.

\section{b.Lapis Tipis Aspal Beton (Lataston, HRS)}

Terdapat dua jenis campuran Lataston yaitu lapis permukaan (HRS-wearing course) dan Lataston untuk lapis pondasi (HRS-Base).

Perbedaan keduanya adalah gradasi Lataston untuk lapis permukaan lebih halus dibandingkan gradasi Lataston untuk lapis pondasi, Lataston untuk lapis permukaan mempunyai tekstur yang lebih halus dibandingkan Lataston untuk lapis pondasi. Lataston sebaiknya digunakan pada jalan dengan lalulintas ringan sampai sedang $(<1.000 .000$ ESA).

Gradasi agregat harus benar-benar senjang. Untuk memperolehnya, hampir selalu diperlukan gabungan antara pasir halus dengan batu pecah. 
Spesifikasi untuk Lataston yang akan digunakan, sebagaiamana diperlihatkan pada tabel berikut :

Tabel 2.1. Ketentuan Sifat-Sifat Campuran Lataston untuk Lalu-lintas

\begin{tabular}{|l|l|c|c|}
\hline \multicolumn{2}{|c|}{ Sifat - sifat Campuran } & \multicolumn{2}{c|}{ Lataston } \\
\cline { 3 - 5 } & WC & BC \\
\hline Penyerapan Aspal (\%) & Max & \multicolumn{2}{|c|}{1,7} \\
\hline Jumlah tumbukan per bidang & & \multicolumn{2}{|c|}{75} \\
\hline Rongga dalam campuran (\%) & Min & \multicolumn{2}{|c|}{3,0} \\
\cline { 2 - 4 } & Max & \multicolumn{2}{|c|}{6,0} \\
\hline $\begin{array}{l}\text { Rongga dalam Agregat (VMA) } \\
\text { (\%) }\end{array}$ & Min & 18 & 17 \\
\hline Rongga terisi aspal (\%) & Min & 68 & \multicolumn{2}{|c|}{800} \\
\hline Stabilitas Marshall (\%) & Min & \multicolumn{2}{|c|}{3} \\
\hline Pelelehan (mm) & Min & \multicolumn{2}{|c|}{250} \\
\hline Marshall Quotient (kg/mm) & Min & 75 \\
\hline $\begin{array}{l}\text { Stabilitas Marshall sisa (\%) } \\
\text { setelah perendaman selama 24 } \\
\text { jam, 60 }\end{array}$ & Min & \multicolumn{2}{|c|}{2} \\
\hline $\begin{array}{l}\text { Rongga dalam campuran (\%) } \\
\text { pada Kepadatan membal ( } \\
\text { refusal) }\end{array}$ & Min & \multicolumn{2}{|c|}{2} \\
\hline
\end{tabular}

Sumber : Spesifikasi seksi 6.3. campuran beraspal panas.

\section{c. Lapis Aspal Beton (Laston, AC)}

Laston (AC) yang umum dikenal terdiri dari tiga, yaitu AC-base, AC-WC1 (AC-binder), dan AC-WC2 (AC-WC). Ukuran butir maksimum ketiganya adalah berturut-turut 11/ 2 inchi, 1 inchi, dan 3/4 inchi.

Laston dapat digunakan untuk lapis permukaan, lapis antara dan lapisan pondasi pada jalan dengan lalu-lintas ringan sampai lalulintas berat. Perbedaan utama dari masingmasing peruntuk tersebut adalah pada ukuran butir maksimum yang digunakan.

Pemilihan ukuran butir maksimum disesuaikan dengan rencana tebal penghamparan, tebal hamparan padat minimum setebal 2 kali ukuran butir maksimum untuk menjamin tekstur permukaan dan ikatan antar butir yang baik. Untuk lapis permukaan diperlukan tekstur yang lebih rapat sehingga lebih kedap terhadap air dan memberi kekesatan yang cukup. Spesifikasi untuk Laston yang akan digunakan, sebagaimana diperlihatkan pada tabel berikut :
Tabel 2.2. Ketentuan Sifat-Sifat Campuran Laston untuk Lalu Lintas

\begin{tabular}{|c|c|c|c|c|}
\hline \multirow{2}{*}{\multicolumn{2}{|c|}{ Sifat - sifat Campuran }} & \multicolumn{3}{|c|}{ Laston } \\
\hline & & \multirow[t]{2}{*}{$W C$} & \multirow[t]{2}{*}{$B C$} & \multirow[t]{2}{*}{\begin{tabular}{|l}
$\mathrm{Ba}$ \\
$\mathrm{se}$ \\
\end{tabular}} \\
\hline Penyerapan Aspal (\%) & Max & & & \\
\hline $\begin{array}{l}\text { Jumlah tumbukan per } \\
\text { bidang }\end{array}$ & & 75 & & $2\left(^{*}\right)$ \\
\hline \multirow{2}{*}{$\begin{array}{l}\text { Rongga dalam campuran } \\
(\%)\end{array}$} & Min & \multicolumn{3}{|l|}{3,5} \\
\hline & Max & \multicolumn{3}{|l|}{5,5} \\
\hline $\begin{array}{l}\text { Rongga dalam Agregat } \\
(\mathrm{VMA})(\%)\end{array}$ & Min & 15 & 14 & \\
\hline Rongga terisi aspal (\%) & Min & 65 & 63 & \\
\hline \multirow{2}{*}{ Stabilitas Marshall (\%) } & Min & \multicolumn{2}{|l|}{800} & 00 \\
\hline & $\operatorname{Max}$ & \multicolumn{2}{|l|}{ - } & \\
\hline Pelelehan (mm) & Min & \multicolumn{2}{|l|}{3} & $\left.{ }^{\star}\right)$ \\
\hline $\begin{array}{l}\text { Marshall Quotient } \\
(\mathrm{kg} / \mathrm{mm})\end{array}$ & Min & \multicolumn{2}{|l|}{250} & b \\
\hline $\begin{array}{l}\text { Stabilitas Marshall sisa } \\
\text { (\%) setelah perendaman } \\
\text { selama } 24 \text { jam, } 60^{\circ} \mathrm{C}\end{array}$ & Min & \multicolumn{3}{|l|}{75} \\
\hline $\begin{array}{l}\text { Rongga dalam campuran } \\
(\%) \text { pada Kepadatan } \\
\text { membal ( refusal) }\end{array}$ & Min & \multicolumn{3}{|l|}{2,5} \\
\hline
\end{tabular}

Sumber : Spesifikasi seksi 6.3. campuran beraspal panas.

\subsection{Pengertian Agregat dan Spesifikasinya}

Agregat adalah suatu bahan keras dan kaku yang digunakan sebagai bahan campuran yang berupa berbagai jenis butiran atau pecahan yang termasuk di dalamnya antara lain pasir, kerikil, agregat pecah, terak dapur tinggi.

Agregat adalah suatu kombinasi dari pasir, kerikil, batu pecah atau kombinasi material lain yang digunakan dalam campuran beton aspal.

Proporsi agregat kasar, agregat halus dan bahan pengisi (filler) didasarkan kepada spesifikasi dan gradasi yang tersedia. Jumlah agregat di dalam campuran aspal biasanya 90 sampai 95 persen dari berat, atau 75 sampai 85 persen dari volume. Agregat dapat diperoleh secara alami atau buatan. Agregat yang terjadi secara alami adalah pasir, kerikil, dan batu. Kebanyakan agregat memerlukan beberapa proses seperti dipecah, dicuci sebelum agregat 
Volume 2 Nomor 2 Oktober 2017

tersebut bisa digunakan. Dalam campuran aspal Shell (1990) mengelompokkan aggregate menjadi 3 (tiga), yaitu :

\section{a.Agregat Kasar}

Agregat kasar yaitu batuan yang tertahan di saringan 2,36 mm, atau sama dengan saringan standar ASTM No. 8. Dalam campuran agregat - aspal, agregat kasar sangat penting dalam membentuk kinerja karena stabilitas dari campuran diperoleh dari interlocking antar agregat.

\section{b.Agregat halus}

Agregat halus yaitu batuan yang lolos saringan No. $8(2,36 \mathrm{~mm})$ dan tertahan pada saringan No. $200(0,075 \mathrm{~mm})$. Fungsi utama agregat halus adalah memberikan stabilitas dan mengurangi deformasi permanen dari campuran melalui interlocking dan gesekan antar partikel.

\section{c.Mineral pengisi (filler)}

Mineral pengisi (filler) yaitu material yang lolos saringan No. $200(0,075 \mathrm{~mm})$. Filler dapat berfungsi untuk mengurangi jumlah rongga dalam campuran, namun demikian jumlah filler harus dibatasi pada suatu batas yang menguntungkan. Terlampau tinggi kadar filler cenderung menyebabkan campuran menjadi getas dan akibatnya akan mudah retak akibat beban lalu lintas, pada sisi lain kadar filler yang terlampau rendah menyebabkan campuran menjadi lembek pada temperatur yang relatif tinggi.

Agregat yang akan digunakan sebagai campuran beraspal panas HRS - Base harus memenuhi persyaratan seperti tercantum pada Tabel 2.3. sebagai berikut :

Tabel. 2.3. Pengujian dan persyaratan untuk agregat dan filler.

\begin{tabular}{|l|l|l|l|}
\hline No. & Pengujian & Metode & Syarat \\
\hline \multicolumn{4}{|l|}{ Agregat Kasar } \\
\hline 1 & Penyerapan air & $\begin{array}{l}\text { SNI 03- } \\
1969-1990\end{array}$ & $<3 \%$ \\
\hline 2 & Berat jenis & $\begin{array}{l}\text { SNI 03- } \\
1970-1990\end{array}$ & $>2,5$ \\
\hline
\end{tabular}

\begin{tabular}{|l|l|l|l|}
\hline 3 & $\begin{array}{l}\text { Keausan I Los } \\
\text { angeles abration test }\end{array}$ & $\begin{array}{l}\text { SNI 03- } \\
2417-1991\end{array}$ & $<40 \%$ \\
\hline 4 & $\begin{array}{l}\text { Kelekatan agregat } \\
\text { terhadap aspal }\end{array}$ & $\begin{array}{l}\text { SNI 06- } \\
2439-1991\end{array}$ & $>95 \%$ \\
\hline 5 & $\begin{array}{l}\text { Partikel pipih dan } \\
\text { lonjong }\end{array}$ & $\begin{array}{l}\text { ASTM D- } \\
4791\end{array}$ & $\begin{array}{l}\text { Maks } \\
10 \%\end{array}$ \\
\hline Agregat Halus \\
\hline 1 & Penyerapan air & $\begin{array}{l}\text { SNI 03- } \\
1970-1990\end{array}$ & $<3 \%$ \\
\hline 2 & Berat jenis & $\begin{array}{l}\text { SNI 03- } \\
1970-1990\end{array}$ & $>2,5$ \\
\hline 3 & Ekivalent pasir & $\begin{array}{l}\text { AASHTO T- } \\
176\end{array}$ & $>50 \%$ \\
\hline Filler & $\begin{array}{l}\text { SNI 15- } \\
2531-199\end{array}$ & $\begin{array}{l}0,5-9 \\
\text { gr/m3 }\end{array}$ \\
\hline 1 & Berat jenis &
\end{tabular}

Sumber : Spesifikasi seksi 6.3. campuran beraspal panas.

\subsection{Gradasi Campuran HRS - Base}

Gradasi atau distribusi partikel-partikel berdasarkan ukuran agregat merupakan hal yang penting dalam menentukan karakteristik perkerasan. Gradasi agregat mempengaruhi besarnya rongga antar butir yang akan menentukan karakteristik dalam proses pelaksanaan di laboratorium maupun di lapangan $(A M P)$. Gradasi agregat dapat dibedakan atas :

a.Gradasi seragam (uniform graded) adalah agregat dengan ukuran yang hampir sama/ sejenis atau mengandung agregat halus yang sedikit jumlahnya sehingga tidak dapat mengisi rongga antar agregat. Gradasi seragam disebut juga gradasi terbuka. Agregat dengan gradasi seragam akan menghasilkan lapisan perkerasan dengan sifat permeabilitas tinggi, stabilitas kurang, berat volume kecil.

b.Gradasi rapat, merupakan campuran agregat kasar dan halus dalam porsi yang seimbang, sehingga dinamakan juga agregat bergradasi baik. Gradasi rapat akan menghasilkan lapisan perkerasan dengan stabilitas tinggi, kurang kedap air, sifat drainase jelek dan berat volume besar.

c. Gradasi senjang (gap graded), merupakan campuran yang tidak memenuhi 2 (dua) kategori di atas. Aggregate bergradasi buruk yang umum digunakan untuk lapisan 
perkerasan lentur merupakan campuran dengan 1 fraksi hilang atau 1 fraksi sedikit. Gradasi seperti ini juga disebut gradasi senjang. Gradasi senjang akan menghasilkan lapis perkerasan yang mutunya terletak antara kedua jenis di atas.

Penentuan distribusi ukuran aggregat akan mempengaruhi kekakuan jenis campuran aspal. Gradasi rapat akan menghasilkan campuran dengan kekakuan yang lebih besar dibandingkan gradasi terbuka. Dari segi kelelehan, kekakuan adalah suatu hal yang penting karena akan mempengaruhi tegangan dan regangan yang diderita campuran beraspal panas akibat beban dinamik lalu lintas.

Spesifikasi baru beton aspal menetapkan gradasi dengan 2 (dua) spesifikasi khusus yaitu target gradasi berada dalam batas titik-titik kontrol dan menghindari daerah penolakan seperti tabel dan gambar berikut.

Titik-titik kontrol berfungsi sebagai batas rentang dimana suatu target gradasi harus lewat titik-titik tersebut diletakkan di ukuran maksimum nominal dan dipertengahan saringan $(2,36 \mathrm{~mm})$ dan ukuran saringan terkecil $(0,075$ $\mathrm{mm})$.

\subsection{Persyaratan Perencanaan Campuran Beraspal Panas}

Perencanaan campuran mencakup kegiatan pemilihan dan penentuan proporsi material untuk mencapai sifat-sifat akhir dari campuran aspal yang diinginkan (Asphalt Institute 1993). Tujuan dari perencanaan campuran aspal adalah untuk mendapatkan campuran efektif dari gradasi agregat dan aspal yang akan menghasilkan campuran aspal yang memiliki sifat-sifat campuran sebagai berikut :

a. Stabilitas adalah kemampuan campuran aspal untuk menahan deformasi permanen yang disebabkan oleh lalu lintas, baik beban yang bersifat statis maupun dinamis sehingga campuran akan tidak mudah aus, bergelombang, melendut, bergeser dan lain-lain.

b.Fleksibilitas adalah kemampuan campuran aspal untuk menahan terhadap defleksi akibat beban lalu lintas tanpa mengalami keretakan yang disebabkan oleh :

1).Beban yang berlangsung lama yang berakibat terjadinya kelelahan pada lapis pondasi atau pada tanah dasar yang disebabkan oleh pembebanan sebelumnya.

2).Lendutan berulang yang disebabkan oleh waktu pembebanan lalu lintas yang berlangsung singkat.

3).Adanya perubahan volume campuran.

c. Durabilitas adalah kemampuan campuran aspal untuk mempertahankan kualitasnya dari disintegrasi atas unsur-unsur pembentuknya yang diakibatkan oleh beban lalu lintas dan pengaruh cuaca.

Campuran aspal harus mampu bertahan terhadap perubahan yang disebabkan oleh :

1).Proses penuaan pada aspal dimana aspal akan menjadi lebih keras. Hal ini disebabkan oleh pengaruh oksidasi dari udara dan proses penguapan yang berakibat akan menurunkan daya lekat dan kekenyalan aspal.

2).Pengaruh air yang menyebabkan kerusakan atau kehilangan sifat lekat antara aspal dan material lainnya.

d.Impermeability adalah campuran aspal harus bersifat kedap air untuk melindungi lapisan perkerasan di bawahnya dari kerusakan yang disebabkan oleh air yang akan mengakibatkan campuran menjadi kehilangan kekuatan dan kemampuan untuk menahan beban lalu lintas.

e.Pemadatan adalah proses pemampatan yang memberikan volume terkecil, menggelincir rongga sehingga batas yang disyaratkan dan menambah kepadatan optimal. Mengingat efek yang timbul oleh pengaruh udara, air serta pembebanan oleh arus lalu lintas apabila rongga dalam campuran tidak memenuhi syarat yang ditentukan. Hal ini harus dihindari supaya tidak terjadi penyimpangan. Pada pelaksanaan pemadatan dilapangan sangat rawan akan terjadinya penyimpangan, baik alat-alat yang digunakan tidak sesuai standar yang ditetapkan maupun jumlah lintasannya. Hughes dalam Fauziah (2001) menyatakan 
bahwa sifat fisik maupun mekanis campuran aspal sangat dipengaruhi oleh teknik pemadatan benda uji, untuk itu pemilihan teknik pemadatan laboratorium berpengaruh sangat nyata terhadap campuran aspal sebagai bahan pembentuk lapis perkerasan jalan. Pemadatan pada hakekatnya adalah untuk memperluas bidang sentuh antar butiran, sehingga mempertinggi internal friction yaitu gesekan antar butiran agregat dalam campuran. Pemadatan merupakan suatu upaya untuk memperkecil jumlah VIM, sehingga memperoleh nilai struktural yang diharapkan.

$f$. Temperatur pemadatan merupakan faktor penting yang mempengaruhi pemadatan, kepadatan hanya bisa terjadi pada saat aspal dalam keadaan cukup cair sehingga aspal tersebut dapat berfungsi sebagai pelumas. Jika aspal sudah dalam keadaan cukup dingin maka kepadatan akan sulit dicapai. Apabila temperatur pada saat pemadatan rendah, mengakibatkan viscositas aspal menjadi tinggi dan membuat sulit dipadatkan. Menaikkan temperatur pemadatan atau menurunkan viscositas aspal berakibat partikel agregat dalam campuran beraspal panas dapat dipadatkan lebih baik lagi, adapun density pada saat pemadatan campuran beraspal panas terjadi pada suhu lebih tinggi dari $275^{\circ} \mathrm{F}\left(135^{\circ}\right.$ C). Density menurun dengan cepat ketika pemadatan dilakukan pada suhu lebih rendah.

g. Workability adalah campuran agregat aspal harus mudah dikerjakan saat pencampuran, penghamparan dan pemadatan, untuk mencapai satuan berat jenis yang diinginkan tanpa mengalami suatu kesulitan sampai mencapai tingkat pemadatan yang diinginkan dengan peralatan yang memungkinkan.

Spesifikasi Baru Beton Aspal Campuran Panas. Spesifikasi ini mengikuti trend perkembangan metoda perencanaan campuran beraspal yang berorientasi pada kinerja. Penyempurnaan spesifikasi campuran beraspal, terutama diarahkan untuk mengantisipasi kerusakan berupa deformasi plastis. Walaupun demikian upaya tersebut dilakukan dengan tidak mengorbankan keawetan dan ketahanan campuran terhadap fatig. Salah satu jenis campuran yang dirangkum dalam spesifikasi baru tersebut adalah HOT ROLLED SHEET BASE ( HRS - Base ).

\subsection{Pengujian Analisa campuran HRS - Base.}

Parameter dan formula untuk menganalisa campuran aspal panas adalah sebagai berikut :

a. Berat Jenis Bulk dari Total Agregat :

$$
\mathrm{G} s b=\frac{\mathrm{P}^{1}+\mathrm{P}^{2}+\mathrm{P}^{3}+\ldots . .+\mathrm{Pn}}{\frac{\mathrm{P}^{1}}{\mathrm{G} s b^{1}}+\frac{\mathrm{P}^{2}}{\mathrm{G} s b^{2}}+\frac{\mathrm{P}^{3}}{\mathrm{G} s b^{3}}+\ldots .+\frac{\mathrm{Pn}}{\mathrm{G} s b n}}
$$

b. Berat Jenis Aparent dari Total Agregat

$$
\mathrm{G} s a=\frac{\mathrm{P}^{1}+\mathrm{P}^{2}+\mathrm{P}^{3}+\ldots . .+\mathrm{Pn}}{\frac{\mathrm{P}^{1}}{\mathrm{Gsa}}+\frac{\mathrm{P}^{2}}{\mathrm{Gsa^{2 }}}+\frac{\mathrm{P}^{3}}{\mathrm{Gsa}^{3}}+\ldots .+\frac{\mathrm{Pn}}{\mathrm{G} s a n}}
$$

c. Berat Jenis Efektif dari Total Agregat

$$
\mathrm{G} s e=\frac{P m m-\mathrm{Pb}}{\frac{\mathrm{Pmm}}{\mathrm{Gmm}}-\frac{\mathrm{Pb}}{\mathrm{Gb}}}
$$

d.Berat Jenis Teoritikal Maksimum dari Campuran (Compacted Mixture)

$$
\mathrm{Gmm}=\frac{\mathrm{Pmm}}{\frac{\mathrm{Ps}}{\mathrm{Gse}}+\frac{\mathrm{Pb}}{\mathrm{Gb}}}
$$

e. Rongga Udara dalam Campuran (Void in the Compated Mixture) dalam persen terhadap total volume :

$$
V I M=100 x \frac{G m m-G m b}{G m m}
$$

f. Rongga dalam mineral agregat (Void in the Mineral Aggregate) dalam persen terhadap total volume :

$$
V M A=100-\frac{G m b X \text { Ps }}{\mathrm{Gsb}}
$$

g. Berat isi atau kepadatan (density) :

$$
\text { Density }=\frac{\text { Berat benda uji di udara }}{\text { Isi benda uji }}
$$


h.Persen rongga terisi aspal (Void Filled with Asphalt) dalam persen terhadap VMA :

$$
V F A=100 x \frac{V M A-V I M}{V M A}
$$

i. Marshall Quotient ( MQ )

$$
M Q=100 \frac{M S}{M F}
$$

Keterangan :

$\mathrm{Gsb}=$ Berat Jenis Bulk total agregat dalam $\mathrm{gr} / \mathrm{cc}$

$\mathrm{P} 1, \mathrm{P} 2, \mathrm{P} 3, \ldots, \mathrm{Pn}=$ Persen berat dari agregat 1 , $2,3, \ldots, n$

Gsb1, Gsb2., Gsbn = Berat Jenis Bulk dari agregat $1,2,3, \ldots, \mathrm{n}$

Gsa = Berat Jenis Apparent dari total agregat Gsa1, Gsa2, , ..., Gsan = Berat Jenis Apparent dari agregat $1,2,3, \ldots, n$

Gse = Berat Jenis Efektif dari total agregat

Gmm = Berat Jenis Teoritis maksimum dari campuran padat tanpa rongga udara.

Pmm = Total campuran yang hilang.

Persen dari total campuran $=100 \%$

$\mathrm{Pb}=$ Kadar aspal dari total berat campuran

$\mathrm{Gb}=$ Berat Jenis dari aspal

Ps = Persentase agregat, persen dari total berat campuran

$\mathrm{Gmb}=$ Berat Jenis Bulk dari campuran

VIM = Void in the Mix (Persen rongga dalam campuran), Persen dari total volume

$V M A=$ Void in Mineral Aggregate (Persen rongga dalam mineral agregat), persen dari volume bulk

VFA = Rongga udara yang terisi aspal, prosentase dari VMA

$M S \quad=$ Stabilitas Marshall

$M F \quad=$ Marshall Flow (kelelehan)

$M Q \quad=$ Marshall Quotient

\subsection{Metode Pengujian Marshall Test.}

Konsep dasar dari metode Marshall dalam campuran aspal dikembangkan oleh Bruce Marshall, seorang insinyur bahan aspal bersama-sama dengan The Mississippi State Highway Department. Kemudian The U.S. Army
Corp of Engineers, melanjutkan penelitian dengan intensif dan mempelajari hal-hal yang ada kaitannya, selanjutnya meningkatkan dan menambah kelengkapan pada prosedur pengujian Marshall dan pada akhirnya mengembangkan criteria rancangan campuran pengujiannya, kemudian distandarisasikan di dalam American Society for Testing and Material 1989(ASTM d-1559).

Dua parameter penting yang ditentukan dalam pengujian tersebut, seperti beban maksimum yang dapat dipikul benda uji sebelum hancur atau Marshall Stability dan deformasi permanen dari sampel sebelum hancur, yang disebut Marshall Flow, serta turunan dari keduanya yang merupakan perbandingan antara Marshall Stability dengan Marshall Flow yang diebut dengan Marshall Quotient, yang merupakan nilai kekakuan berkembang (speudo stiffness), yang menunjukkan ketahanan campuran beraspal terhadap deformasi permanen (Shell, 1990).

Pada sebagian besar agregat, daya ikat terhadap air jauh lebih besar jika dibandingkan terhadap aspal, karena air memiliki wetting power yang jauh lebih besar dari aspal. Keberadaan debu yang berlebihan pada agregat juga akan berakibat kegagalan pengikatan ataupun berakibat munculnya potensi kehilangan daya ikat campuran beraspal.

Uji perendaman Marshall (Marshall Immersion Test) merupakan uji lanjutan dari uji Marshall sebelumnya, dengan maksud mengukur ketahanan daya ikat/adhesi campuran beraspal terhadap pengaruh air dan suhu (water sensitivity and temperature susceptibility). Ada beberapa cara yang digunakan untuk menilai tingkat durabilitas campuran beraspal, salah satunya adalah dengan mencari Marshall Retained Strenght Index atau dengan cara lain yaitu dengan menghitung Indeks Penurunan Stabilitas. Perbedaan keduanya adalah dasar perbandingan dari variasi lamanya perendaman dalam alat waterbath. Prosedur pengujian durabilitas mengikuti rujukan SNI M-58-2990. 


\section{$\square \quad 165 \mid$ JUTEKS Jurnal Teknik Sipil}

\section{METODE PENELITIAN}

\subsection{Lokasi Penelitian}

Lokasi pelaksanaan penelitian dilaksanakan di Laboratorium Jurusan Teknik Sipil Politeknik Negeri Kupang, Kota Kupang - Nusa Tenggara Timur.

Lokasi stockpile berada pada kali Ex. Pariti unit Hot Feed Bin AMP Bipolo milik CV. PANCA Konstruksi (HMN), Kabupaten Kupang - Nusa Tenggara Timur.

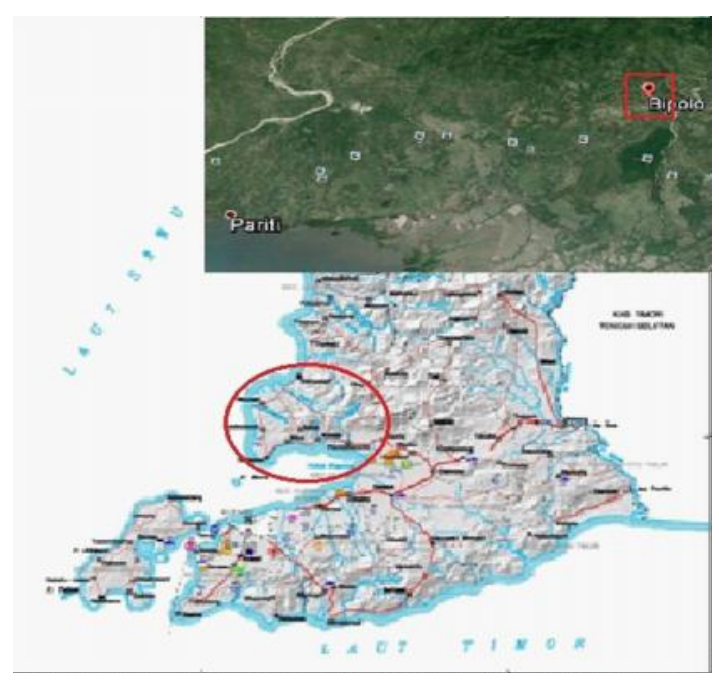

Gambar 3.1. Peta lokasi stockpile AMP Bipolo Sulamu, Kabupaten Kupang - Nusa Tenggara Timur

\subsection{Tahapan Penelitian}

\section{Pengujian Bahan}

Pengujian Bahan meliputi : pengujian aspal, pengujian agregat dan filler.

1.Pengujian aspal.

Aspal yang digunakan adalah aspal Pertamina dengan penetrasi 60/70 dan pengujian yang dilakukan terhadap aspal tersebut adalah seperti pada Tabel 2.1.

2.Pengujian agragat dan Filler.

Untuk keperluan pengujian di laboratorium Agregat kasar dan halus diambil dari hasil pengolahan Stock pile di AMP Bipolo CV. PANCA Konstruksi, dimana Agregat kasar bergradasi lolos saringan 3/4" tertahan \#8 dan agregat halus bergradasi lolos saringan \#8

\section{Volume 2 Nomor 2 Oktober 2017}

tertahan \#200. Bahan pengisi (filler) yang digunakan di dalam penelitian ini adalah abu batu sekurang - kurangnya $80 \%$ dari material ini disyaratkan lolos saringan No. 200. Untuk keperluan pengujian dari lapangan bahan diambil dari Cold Bin I (pasir), Cold Bin II (abu batu), Cold Bin III (agregat kasar 1/2"), dan Cold Bin IV (agregat kasar 3/4") AMP. Pengujian dan persyaratan untuk agregat dan filler dapat dilihat pada Tabel 2.5.

\subsection{Teknik Pengumpulan Data.}

1.Pengambilan Sampel (Sampling).

Penulis mengambil beberapa sampel (contoh) material (aspal, agregat) untuk dijadikan bahan penelitian. Data yang dikumpulkan dari pengambilan Sampel (Sampling) berupa data primer.

2.Pengujian di Laboratorium.

Pengujian (penelitian) di Laboratorium. Data yang dikumpulkan dari pengujian berupa data primer.

\section{HASIL DAN PEMBAHASAN}

\subsection{Gambaran Umum Penelitian}

Penelitian ini merupakan penelitian experimental yang berkaitan dengan rancangan campuran material perkerjaan HRS-Base dengan menggunakan aspal padat penetrasi 60/ 70 ex Pertamina. Rancangan campuran ini diharapkan dapat digunakan lapisan permukaan jalan raya jenis perkerasan lentur untuk pekerjaan peningkatan perkerasan jalan.

Pelaksanaan penelitian ini dilakukan di Laboratorium Pengujian Bahan Politeknik Negeri Kupang Jurusan Teknik Sipil. Penelitian ini dilaksanakan dari tanggal 25 Oktober sampai dengan 18 Nopember 2016.

\subsection{Analisa dan Pembahasan Pemeriksaan Keausan Agregat Kasar dengan Mesin Abrasi Los Angeles}

Ketahanan agregat terhadap penghancuran atau keausan dapat diperiksa dengan menggunakan mesin abrasi Los Angeles. Nilai akhir dari pengujian ini dinyatakan dalam persen 
yang merupakan perbandingan antara berat benda uji semula dikurangi berat benda uji tertahan saringan no. 12. Jika nilainya lebih besar dari $40 \%$, maka material tersebut tidak boleh digunakan, semakin kecil nilai keausan yang didapat (0-40\%) maka ketahanan agregat tersebut terhadap keausan semakin baik, demikian pula sebaliknya. Hasil pengujian dan perhitungan keausan agregat kasar dengan mesin abrasi Los Angeles diperoleh nilai Keausan agregat kasar sebesar 37,6 \% atau memenuhi spesifikasi keausan sebagai agregat kasar.

\subsection{Analisa dan Pembahasan Pemeriksaan Gradasi Agregat Kasar dan Agregat Halus (Agregat Gabungan)}

Hasil uji gradasi agregat kasar dan agregat halus menunjukkan tidak terlampaui batas atas dan batas bawah dalam spesifikasi agregat campuran.

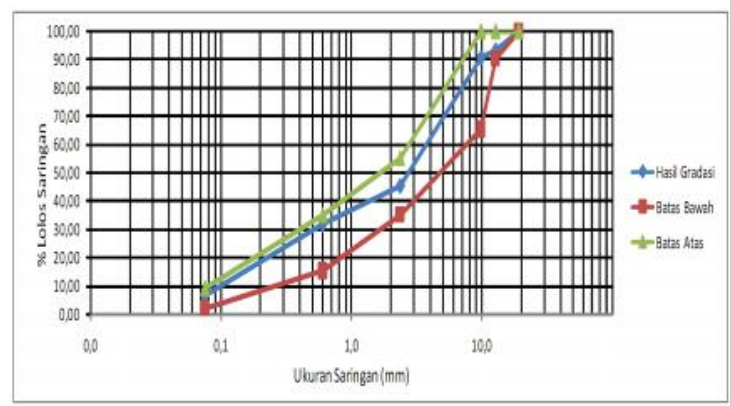

Gambar 4.2. Gradasi Gabungan

\subsection{Analisa dan Pembahasan Hasil Pengujian untuk VIM-PRD}

Pengujian rongga dalam campuran pada kepadatan mutlak (VIM-PRD) dilakukan untuk mengetahui kepadatan campuran HRS-Base setelah jalan tersebut dilalui oleh kendaraan (telah menerima beban lalu lintas). Kadar aspal yang digunakan untuk membuat benda uji adalah kadar aspal dengan VIM 6,5\%. Hasil kadar aspal dengan VIM 6,5\% kemudian diambil dua variasi kadar aspal masing-masing satu kadar aspal di atas dan di bawah nilai tersebut yaitu : $6 \%$ dan $7 \%$, sehingga diperoleh tiga kadar aspal yaitu $(6 \%, 6,5 \%, 7 \%)$ dengan 1 kadar aspal dibuat 2 buah benda uji.

Hasil dan analisis pengujian campuran HRS-Base untuk mendapatkan kepadatan mutlak (VIM-PRD) dapat dilihat pada tabel 4.1 ini.

Tabel 4.1. Hubungan antara Kadar Aspal dan Parameter-parameter Kepadatan

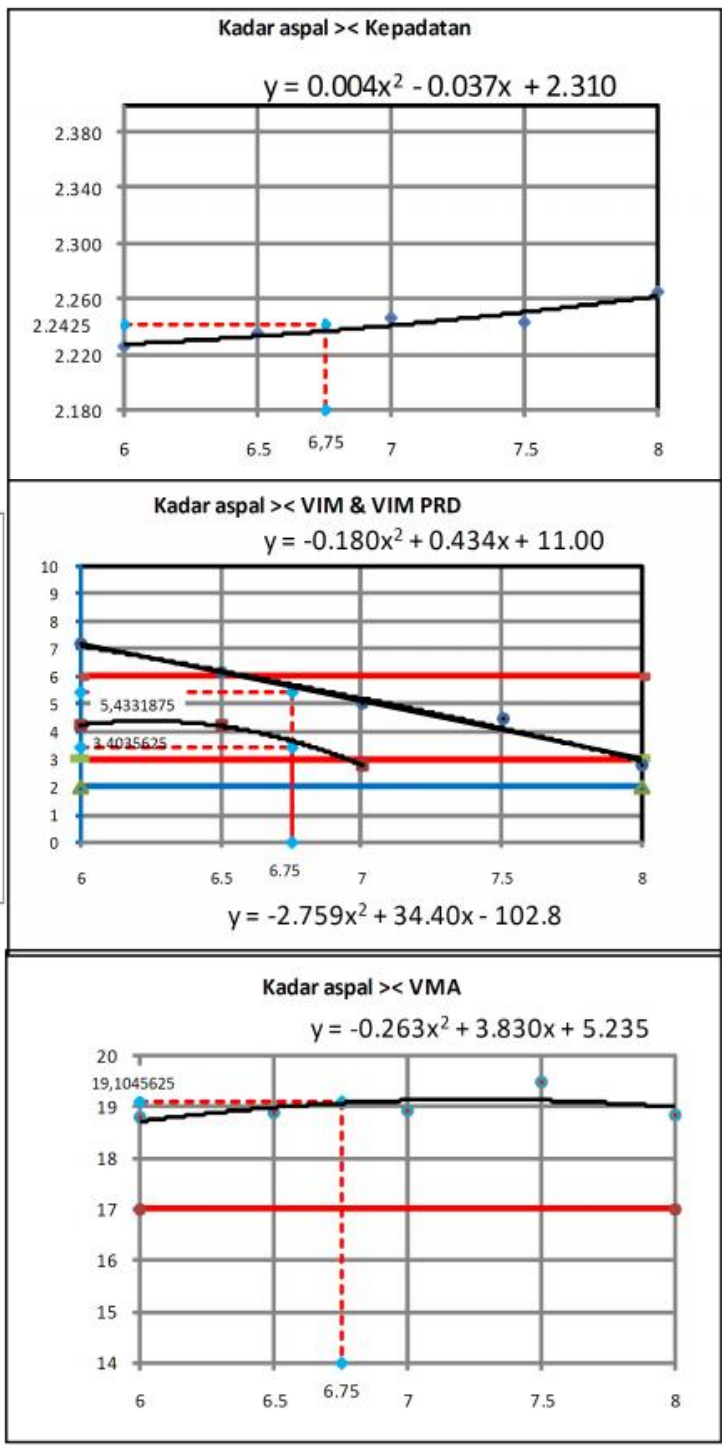




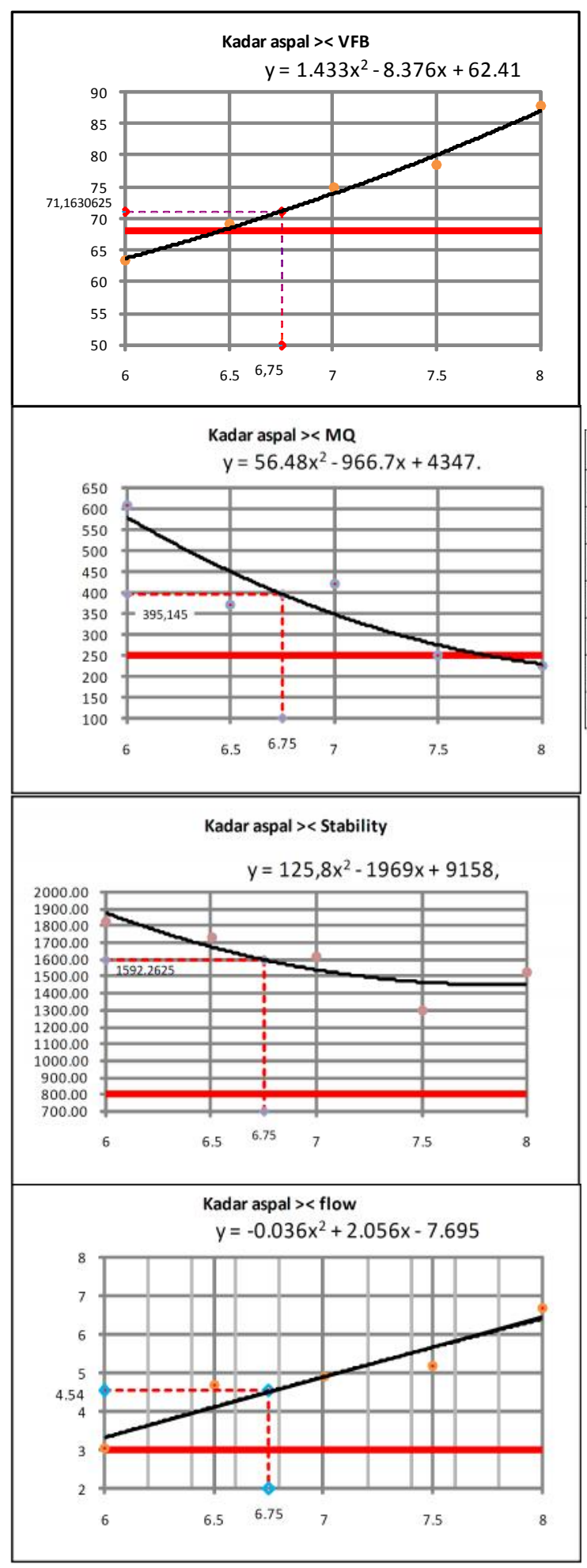

\subsection{Evaluasi Sifat-Sifat Campuran Aspal}

Evaluasi sifat-sifat campuran dan kadar aspal yang memenuhi spesifikasi seperti yang ditunjukkan pada tabel 4.2 untuk mendapatkan nilai kadar aspal optimum. Dari tabel 4.2 diperoleh nilai kadar aspal optimum yaitu $\mathbf{6 , 7 5}$ \% merupakan kadar aspal yang menghasilkan sifat campuran terbaik yang memenuhi semua spesifikasi.

Tabel 4.2. Evaluasi Sifat - Sifat Campuran Aspal HRS-Base

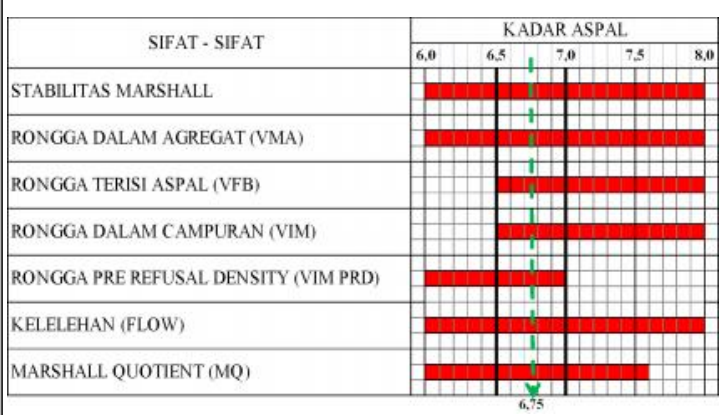

Dari hasil perhitungan hubungan parameter Marshall dan kadar aspal diperoleh sifat-sifat campuran aspal yang memenuhi spesifikasi adalah sebagai berikut :

Tabel 4.3. Sifat-Sifat Campuran Aspal

\begin{tabular}{|c|l|c|c|c|c|}
\hline No & \multicolumn{1}{|c|}{ Sifat - Sfat } & Nilai & Satuan & Spesifikasi & Keterangan \\
\hline 1 & Kadar aspal optimum & 6,75 & $\%$ & - & Tidak disyaratkan \\
\hline 2 & Kepadatan & 2,2425 & $\mathrm{~g} / \mathrm{cm}^{3}$ & - & Tidak dișaratkan \\
\hline 3 & Rongga dalam agregat (VMA) & 19,10456 & $\%$ & Min I7 & Memenuhi \\
\hline 4 & Rongga terisi aspal (VFB) & 71,163063 & $\%$ & Min 68 & Memenuhi \\
\hline 5 & Rongga dalam campuran (VIM) & 5,72825 & $\%$ & $3-6$ & Memenuhi \\
\hline 6 & Rongga dlm campuran padat (VIM PRD) & 3,6931 & $\%$ & Min 2 & Memenuhi \\
\hline 7 & Stabilitas & 1599,0125 & $\mathrm{Kg}$ & Min 800 & Memenuhi \\
\hline 8 & Marshall Quotient (MQ) & 395,145 & $\mathrm{Kg} / \mathrm{mm}$ & Min 250 & Memenuhi \\
\hline 9 & Kelekhan Marshall (Flow) & 4,54275 & $\mathrm{~mm}$ & Min 3 & Memenuhi \\
\hline
\end{tabular}

\section{KESIMPULAN}

Dari hasil pengujian dan pembahasan sebelumnya, dapat diambil kesimpulan terhadap penelitian aplikasi gradasi gabungan di Laboratorium dengan Hot Bin AMP untuk campuran Lataston (HRS-Base) terhadap nilai karakteristik Marshall ini sebagai berikut :

A.Hasil uji gradasi di Hot Bin AMP dapat terkendali dengan baik sehingga memberikan hasil 
nilai karakteristik Marshall juga yang sangat rapat sesuai rencana, sedangkan hasil gradasi laboratorium terlihat lebih kasar.

B.Perbandingan antara Gradasi Gabungan di Laboratorium dengan Hot Bin AMP untuk campuran HRS-Base terhadap nilai Marshall, kecuali pada VIM dan Flow pada kadar aspal $5 \%$ (Hot Bin) dan 5,5\% - 6\% laboratorium yang tidak memenuhi spesifikasi. Nilai density, VIM, Stabilitas dan MQ dilaboratorium lebih rendah dari Hot Bin di AMP sedangkan nilai VMA, VFA dan Flow di Laboratorium lebih tinggi dari Hot Bin di AMP.

C.Dari evaluasi nilai-nilai parameter Marshall ini secara aplikasi dapat dikatakan bahwa kinerja campuran Lataston (HRS-Base) dari gradasi gabungan di Hot Bin akan lebih kaku (rigid), kokoh, stabil dan tahan terhadap deformasi plastis sekaligus lebih mampu menahan beban lalulintas yang sifatnya lebih berat dan padat.

\section{DAFTAR PUSTAKA}

Departemen Pekerjaan Umum, 1999, Pedoman Perencanaan Campuran Beraspal Panas DenganPendekatan Kepadatan Mutlak, No 023/T/BM/1999, Puslitbang Jalan, Bandung.

Departemen Pemukiman dan Prasarana Wilayah, 2002, Spesifikasi Baru Beton Aspal Campuran Panas, Puslitbang Prasarana Transportasi, Bandung.
Departemen Pekerjaan Umum, 2002, Pedoman Perencanaan Tebal Perkerasan Lentur, Penerbit Departemen Permukiman Dan Prasarana Wilayah.

Departemen Pekerjaan Umum. 1987, “ Petunjuk Pelaksanaan Tebal Perkerasan Lentur Jalan Raya Dengan Metode Analisa Komponen.

Modul Praktek Pengujian Bahan II, 2012, Jurusan Teknik Sipil, Politeknik Negeri Kupang.

Revisi SNI 03-1737-1989, Pelaksanaan Lapis Campuran Beraspal Panas.

Saodang Hamirhan, 2004, Konstruksi Jalan Raya, Perancangan Perkerasan Jalan Raya, Bandung, Nova.

Sukirman Silvia, 1999, Perkerasan Lentur Jalan Raya Cetakan Kelima, Bandung, Nova.

Sukirman Silvia, 2003, Beton Aspal Campuran Panas, Jakarta, Granit.

Sukirman, Silvia, 2010, Perencanaan Tebal Struktur Perkerasan Lentur, Bandung.

Suprapto, T.M, 2004, Bahan Dan Struktur Jalan Raya, Biro Penerbit Teknik Sipil, Universitas Gadjah Mada, Yogyakarta. 